\title{
Human Rights Violations during Armed Conflict in Nepal
}

- $\quad$ Prem Raj Khanal ${ }^{1}$

\begin{abstract}
The armed conflict of Nepal was a conflict between government forces and Maoist rebels which started from 13 February 1996 and lasted 21 November 2006. The Communist Party of Nepal (Maoist) had begun the war with the aim of overthrowing the Nepalese monarchy and establishing the "People's Republic of Nepal." A decadelong armed conflict was formally ended with signing of the "Comprehensive Peace Accord (CPA)" between government of Nepal and Communist Party of Nepal (Maoists) on 21 November 2006. This article does not describe the political, economic and other dimension of the armed conflict in Nepal. However, it tells about the different aspects of the human rights violations by State and Maoists in a decade-long (from 1996 to 2006) war in Nepal.
\end{abstract}

Keywords :

Human rights, conflict, Maoist, CPA

\section{Introduction:}

According to Informal Sector Service Centre (INSEC) - one human rights organization in Nepal, more than 13,000 people were killed and an estimated 100,000 to 150,000 people were internally displaced as a result of the conflict. State and Maoist violated the human rights and international humanitarian law (IHL) during the armed conflict. IHL governs the conduct of parties involved in armed conflicts. Geneva Conventions applies to non-international armed conflicts. Nepal has ratified the four Geneva Conventions but has not ratified the two Protocols. By virtue of Nepal's ratification of the four Geneva Conventions, both the Nepalese security forces and the CPN-M are bound by common Article 3 of the Geneva Conventions. In addition, both parties are also bound by customary law applicable to internal armed conflicts. According

1 He is an Assistant Professor at Master's in International Relations and Diplomacy (MIRD) program under Tribhuvan University. His areas of interest are diplomacy, foreign policy, human rights and international humanitarian law. He can be reached at khanal.prem@gmail.com 
to Office of the High Commissioner for Human Rights in Nepal (OHCHR), both parties committed serious violations of IHL, principally endangering the lives of the civilian population, including through launching attacks in civilian areas; using civilian houses and schools as shields; indiscriminate bombing; abandoning of explosive devices in areas frequented by civilians; and the use of children.

\section{Right to Life}

Right to life is the most important fundamental right of human. According to the Universal Declarations of Human Rights (UDHR), article three, "Everyone has right to life, liberty, and security of person". Article six of the International Covenant on Civil and Political Rights says "Every human being has the inherent right to life. This right shall be protected by law. No one shall be arbitrarily deprived of his life." In 1776, the United States Declarations of Independence declared that all men are endowed with certain inalienable rights and that "among these are life, liberty and the pursuit of happiness". Nepal signed the Universal Declarations of Human Rights and other International Human Rights laws. But during the armed conflict, Nepal government does not able to protect the people's fundamental human rights. For example, more than 13,000 people were killed and thousands of people were displaced during the conflict. According to INSEC, 13,347 people were killed between the 13 February 1996 and 31 December 2006. Out of them, 8,377 persons were killed by state and 4,970 persons were killed by Maoist. There were sharp increases in the number of human rights violations particularly after November 2001 when the Royal Nepalese Army (RNA) was deployed. From November 2002, the Nepal Police (NP) and the Armed Police Force (APF) were placed under the "unified command" of the RNA for counterinsurgency operations (inseconline.org.np).

One the one hand, Maoist attacked police stations, government officials and also targeted suspected informants, landowners, and civilians. By abducting civilians and forcing some to give them shelter or to join their troops, Maoists imposed an increasingly authoritarian regime on many parts of rural Nepal. The Maoist rebellion has been waged through torture, killings, and bombings involving civilians and public officials. On the other hand, State security persons killed the civilians, gave torture to them, assuming they were helping Maoist. Security person also killed Maoist illegally. Without any proof, security persons killed the civilians assuming they were Maoist supporters.

Nepalese common people were trapping in-between both State and Maoist. Nepalese villagers would often find themselves caught in the middle of the conflict. Maoists gave the pressure to civilians for money, foods, and shelter. But, State 
security person punished civilians assuming that they were helping Maoist. So, common people were faced double pressure and threaten by State security and Maoist. During conflict period, both the parties were involved in extra judicial killing, torture, enforced disappearance, illegal detention, displacement of people. They violated the rights of the children and women, explosion of ammunition causing human deaths and injuries, violation of various economic and social rights.

According to the Ban Landmines Campaign Nepal, both the army and the Maoists have been using landmines, which have victimized civilians more than the combatants. Both the rebels and security forces targeted civilians; the rebels attacking those deemed "enemies of the people," including politicians and teachers, and government forces targeting those perceived to be supportive of the Maoist cause. The rebels used guerrilla tactics such as ambushes, landmine, and bombing. For example, 6 June 2005, in Badarmude bus explosion, 38 civilian were killed and over 70 injured after a packed passenger bus runs over a rebel landmine in Chitwan district. In conclusion, State and Maoists both were commitment to respect the fundamental human rights and humanitarian laws. But in practice, both the parties were failed to protect human rights (Nepal.icbl.org).

\section{Civil and Political Rights}

According to the International Covenant on Civil and Political Rights (ICCPR), Part I Article 1, "All peoples have the right of self-determination. By virtue of that right they freely determine their political status and freely pursue their economic, social, and cultural development." Nepal government accession ICCPR on 14 May 1991. But, during the armed conflict, both government and Maoist violated the civil and political rights of the people. Individual political freedom, rights of individuals, freedom of thought, freedom of speech and expression, freedom of press, freedom of movement all rights are violated during the armed conflict in Nepal. For example, for Maoist side, they killed the people, give the torture to the people, they stopped the people for movement from one place to other place of Nepal. They violated the people right to privacy, right to peaceful assembly, rights of self-determination. Maoist closed the thousands of schools, kidnapped the student and teacher, and gave to threaten to the school administration, give pressure for money.

According to INSEC report, during armed conflict, 145 teachers and 344 students were killed by state and Maoist. By the name of justice, Maoist run the "JANA AADALAT" (people court) and gave the decision whatever they want. They violated the people rights to natural justice in law. For example, Maoist killed the journalist and 
threatens other journalist and people who do not believe and support their views. For example, 15 February 2004, Ganesh Chilwal who leaded an anti-Maoist protest, was shot killed in his Kathmandu office by two suspected Maoist. Nepali citizen must ask for permission to Maoist for visit in different part of the Nepal. Sometimes, they did not give the permission to the people. Maoist violated the people rights to freedom of movement. Mainstream political parties were unable to run political programme in most of the districts due to Maoist threaten.

Government had also violated civil and political rights of the people. For example, security person of the state captured the civilians assuming they were Maoist and killed illegally. Especially, when King Gyanendra took the power in his hand, Neplai Press faces the directly censor from government. F.M radios were compelled to stop the news. But F.M stations were very much popular to increase the political awareness in Nepali community. Nepal armies censor the news from news room of the media. According to INSEC, nine journalists were killed by State and four were from Maoist side during the armed conflict. State were not successes to respect the citizens' rights to individual dignity, freedom and movement include protection against torture, and inhuman behaviour, against abduction or unwarranted detention, freedom to movement, respect of secrecy as provisioned by law, and right of the displaced and their family members to live in their original settlement or a place of their choice. The security persons of state were involved inhuman behaviour and incidents of assault were found during this period as well. Both parties gave torture and thrashing, inhuman and dishonourable activities to the people.

\section{Disappearance}

For many families in Nepal, the pain of war is continues now. They searched to find out their relatives forcibly disappeared during the conflict. During those 10 years long conflict, hundreds of people were arrested and interrogated by the army, and many remain missing to this day. The International Red Cross has a list of 937 people reportedly disappeared by the authorities, while the UN has documented around 500 cases. Sandra Beidas, chief of protection at the UN Office of the High Commissioner for Human Rights, told that the impact of disappearances on families is enormous. She said "Obviously not knowing whether their loved ones are alive or dead, what happened to them is just a constant anguish, and in a sense it's a form of mental torture." There were no detailed investigations about disappear people. Human Rights Watch said "The Nepal government has failed to conduct credible investigations and to prosecute those responsible for thousands of extrajudicial killings, torture, and enforced disappearances 
three years after the end of the country's decade-long armed conflict"

The UN has made detailed investigations of 49 people who reportedly disappeared from an army barracks in Kathmandu in late 2003. The case has become a high profile test of the army and government, yet despite the UN's report of imprisonment, torture and disappearances from the barracks. Sandra Beidas says "We know that there was an army task force that investigated the cases but the army did not give us a copy." But, the Nepal Army did not accept the human rights violation in BhairabNath barrack case. In 2007, Nepal's Supreme Court ruled that 83 people who were missing, were in fact taken by the security forces and ordered compensation to be paid to families. The Court also recommended the government form a high-level commission to investigate disappearances and punish those responsible. Many individuals and families were internally displaced during the armed conflict.

In conclusion, during the conflict, there were no genuine elections at all. The citizens' right to vote and to be elected were bounded. The people, deprived of their basic political right to vote and to be elected for long, got a chance to exercise their fundamental political right. In this period, right to freedom of opinion and expression, establishing organizations, peaceful assembly, voting and being elected, right against exploitation and right to information were violated by State and Maoists.

\section{Economic, Social, and Cultural Rights}

International Covenant on Economic, Social and Cultural Rights (ICESCR) part I, article 1(1) says "All peoples have the right of self-determination. By virtue of that right they freely determine their political status and freely pursue their economic, social, and cultural development." Economic and Social Rights of people during conflict period were violated by State and Maoist. Nepalies people could not enjoy their economic and social rights such as rights to employment and livelihood, right to food, right to health, right of workers, social security, family life and right to property.

On the one hand, to search employment and social security, thousands of Nepalese continued to go abroad as migrant workers due to the war. In the failure to create opportunities of employment within the country, thousands of Nepalese youth compelled to go abroad. On the other hand, Maoist rebels bombarded larger regions, cut telephone and electricity lines and enforced economic and transport blockades in Kathmandu. Maoists forcefully collected tax, cash against people will; they robbed the bank, they looted the civilian land, property.

Because of conflict, health workers did not go to village and rural part of the 
country. The health post continued to face the shortage of health workers, medicine and equipment during the conflict period. There was a lack of health workers and medicine in time of an outbreak of diarrhea in some hilly and Tarai districts. In the last year, about 400 people died of diarrhea due to the lack of medical practitioners and medicine in some Mid and Far-Western districts, including Jajarkot. Some patients died on the way, while being taken to hospital, due to protest (bandh), strike and blockade called, in a grave violation of citizens' fundamental rights. Both parties were failed to respect the citizens' right to health.

Children were deprived of their right to education due to strike and blockade. Political parties were using children in protests and demonstrations of various kinds. Shortage of teachers in proportion to the number of students violated the rights to education for student during the period. Students and teachers were abducted by State and Maoists. For example, 11 November 2003, the government Defence Ministry said the Maoists abducting twenty-nine 9th and 10th grade students from Riva Secondary School western Nepal in Mugu District. The slogan of 'Schools: A Peace Zone' could not materialize in the period. During the last period of conflict, Maoist cadres staged vandalism and arson at District Education Office Dhankuta, the manager of education in the district. In August 2005, Maoist cadres obstructed teaching learning activities at a school situated in Birauta of Pokhara.

The Maoist seized the property of civilian and government. One the one hand, Maoist captured the property from individuals, organizations and government. Maoist cadres collected forced donations, held houses belonging to individuals and did not return all buildings and land held during the insurgency. On the other hand, security forces not vacating the land used by them during the armed conflict for the safety of their camps. In Siraha, residents of Badarmala VDC staged an agitation citing that Nepali Army had not returned property. In October, the National Human Rights Commission (NHRC) said received that local Maoist cadres seized houses belonging to six individuals in Sankhuwasabha. There were reports of Maoist cadres seizing and distributing among the local landless 147 bigaha 13 kattha land area in Sunsari's Chhitaha VDC. NHRC continued to receive reports of land seizure during the period.

\section{Child Rights}

Nepal signed the Convention on the Rights of Child on 8 September 2000. But, Nepal was not successes to protect the child rights during armed conflict. During the armed conflict period, children were used by both Maoist and Nepalese Army. According to UNICEF, children were used in a "wide range of role including as spies, porters, 
and combatants". Maoist compelled individuals less than 18 years of age to join their armies. Because of war, child rights to educations, health and nutrition were affected. According to the CWIN- a organization in Nepal for the rights of children, 402 children were directed affected by conflict. For example, 18 August 2004, a 12 -year- old boy was killed and six others were wounded due to a bomb exploded in a marketplace in southern Nepal. Another organization, INSEC said 344 students were killed during the 10 years long war. Out of them, 204 students were killed by state and 140 students were killed by Maoist. UN special representative on children Radhika Kumaraswami expressed her concern that there was not expected improvement in the condition of conflict-hit children, and that they could not be rescued and sheltered according to the provisions of the CPA. In violation of the CPA, children were brought in large numbers by the Maoists to their Singhadurbargherao programme on Kartik 26 and 27. Other conflict-hit children could not be effectively rehabilitated during the period.

\section{Women Rights}

State and Maoist both violated the women rights during the armed conflict. Women were faces the problem of sexual exploitation and misbehaviour by state security person and Maoist. For example, on 17 February 2004, Maina Sunuwar 15 -year-old girl died in military custody after she was subjected to electrocution and drowning during interrogation. Nepal Army Major Niranjan Basnet was charged with murdering 15-year-old girl. Amnesty International Asia Pacific Director Sam Zarifi said "The Nepali government has failed to provide accountability for the many atrocities committed by Nepali security forces as well as Maoist cadres during Nepal's civil war. The resulting culture of impunity undermines the rights of victims and their families, and potentially carries over to the Army's involvement in UN missions." Major Basnet was recently expelled from the United Nations Mission in Chad because of his human rights record and repatriated to Nepal, but the army has so far refused to hand him to the civilian authorities. (amnesty.org)

Women's right to reproduction and reproductive health; physical, mental and any kind of violent activity against women to be punishable and equal right to ancestral property were not preserved by State and Maoist.

\section{Conclusion}

In conclusion, during this period both the parties were found involved in various cases of human rights violation such as extra judicial killing, torture, enforced disappearance of human persons, illegal detention, displacement, rights of the child and women, explosion of ammunition causing human death and injuries followed by violation 
of various economic and social rights. The management of arms of both the parties helped improve the human rights situation as well. In the Comprehensive Peace Accord to generalization of mutual relationship and to create the environment for reconciliation it, especially, all the political parties need to take personal and collective responsibility including with civil society and with help of the organization, but the main political parties did not take part in resolving the problem with rising up above the political parties ambition for it is mentioned that in order to resolve the problem which are arose up because of struggle. The government must establish the Truth and Reconciliation Commission and Commission of Inquiry on Disappearances as soon as possible. The government follow the Supreme Court order to establish high-level Commission to investigate disappearance and punished those responsible. Nepal government conduct credible investigations and punish those responsible for thousand extrajudicial killings, torture, and enforced disappearances during the decade long armed conflict.

\section{Works Cited:}

Amnesty International (2009), 'Nepal Must Bar Human Rights Violators from UN Peacekeeping Mission’ Avaliable online at : http//www.amnesty.org/en/news-andupdates/Nepal-must-bar (Accessed 3 February 2010).

Ban Landmines Campaign Nepal (2006) 'Lobbing and Advocacy’ Available online at: http:// www.nepal.icbl.org (Accessed 1 February 2010).

Baylis, J., Smith, S., and Owens, P. (2008) The Globalization of World Politics. 4th ed. Oxford University Press: NY.

Berridge, G.R. (1992), International Poltics: States, Power and Conflicts Since 1945, Harvester Wheatseaf.

Buzan, A. (1984), Peace, Power, and Security. Contending Concepts in the Study of International Relations 21 (2) 109-125.

CWIN Nepal(2009). ‘Annual Report 2006' Available online at: http://www.cwin.org.np (Accessed 2 February 2010).

Government of Nepal Ministry of Peace and Reconstruction (2009) 'Comprehensive Peace Accord Concluded Between the Government of Nepal and The Communist Party of Nepal (Maoist)'. Available online at:http:// www.peace.gov.np/admin/doc/CAP-eng-vercorrected.pdf (Accessed 1 February 2010).

James, P. and Nairn, T. (2006) Globalization and Violence. Saga Publications: London Informal Sector Service Center (INSEC) ‘Annual Report 2006’. Available online at:http:// 
www.insec.org.np/index.php. (Accessed 1 February 2010)

International Committee of the Redcross (ICRC) 'Nepal:where have the missing gone?'.

Available online at: http:// www.icrc.org/web/eng/(Accessed 1 February 2010).

Kantipur News Available online at: http:// www.ekantipur.com (Accessed 1 February 2010).

Landman, T. (2006) Holding the Line: Human Rights Defenders in the Age of Terror. The British Journal of Politics and International Relations, 8 (2), 123-147.

Millennium Development Goals (2008) 'Combat HIV/AIDS, Malaria and other Diseases'.

Avaliable online at:http://www.un.org/millenniumgoals/aids.shtml (Accessed 2 February 2010).

Human Rights Watch (2010) 'Nepal: Years of Terror, Then Broken Promises' Available online at: http://www.hrw.org/en/news/2009/10/15/Nepal-years-terror-broken-promises (Accessed 2 February 2010).

Nagarik News Available online at: http://www.nagariknews.com (Accessed 1 February 2010).

National Human Rights Commission, Nepal (2009) 'Three-Year Comprehensive Peace Accord (CAP) Summary Report 2006-2009'. Available online at: http://www.nhrcnepal. org (Accessed 2 February 2010).

Office of the United Nations High Commissioner for Human Rights. Available online at: http:// www2.ohchr.org/English/law/ccpr.htm (Accessed 1 February 2010).

Republica News Available online at: http://www.myrepublica.com (Accessed 1 February 2010).

The Universal Decleration of Human Rights. Avaliable online at :http://www.un.org/en/ documents/udhr/ (Accessed 1 February 2010).

UNICEF, (2005) 'Children Affected by Armed Conflict'. Available online at: http://www. unicef.org/nepal/5522_children_affected_by_armed_conflict.htm. (Accessed 2 February 2010).

United Nations Mission in Nepal (2009) 'Latest News' Available online at: http://www.unmin. org.np (Accessed 1 February 2010).

World Food Proframme (2009) 'World Hunger’ Available online at: http://www.wfp.org/ hunger (Accessed 2 February 2010). 
